\title{
Correction to: Manual joint mobilisation techniques, supervised physical activity, psychological treatment, acupuncture and patient education for patients with tension- type headache. A systematic review and meta-analysis
}

Lotte Skytte Krøll ${ }^{1 *}$, Henriette Edemann Callesen², Louise Ninett Carlsen ${ }^{1,3}$, Kirsten Birkefoss ${ }^{4}$, Dagmar Beier ${ }^{5}$, Henrik Wulff Christensen ${ }^{6}$, Mette Jensen ${ }^{7}$, Hanna Tómasdóttir ${ }^{8}$, Hanne Würtzen ${ }^{9}$, Christel Vesth Høst ${ }^{3}$ and Jakob Møller Hansen ${ }^{1,3}$

Correction to: J Headache Pain 22, 96 (2021) https://doi.org/10.1186/s10194-021-01298-4

Following the publication of the original article [1], we were notified that the quality for Fig. 1 needed improvement. The presentation of the data in Fig. 1 has not changed.

The original article has been corrected.

\begin{abstract}
Author details
'Department of Neurology, Danish Headache Centre, Rigshospitalet-Glostrup, University of Copenhagen, Valdemar Hansens Vej 5, 2600 Glostrup, Denmark. ${ }^{2}$ Metodekonsulent Callesen, Åhavevej 26, 8600 Silkeborg, Denmark. ${ }^{3}$ Danish Knowledge Centre on Headache Disorders, Rigshospitalet-Glostrup, University of Copenhagen, Valdemar Hansens Vej 5, 2600 Glostrup, Denmark. ${ }^{4}$ Danish Health Authority, Islands Brygge 67, 2300 Copenhagen S, Denmark. ${ }^{5}$ Department of Neurology, Odense University Hospital and University of Southern Denmark, Sdr. Boulevard 29, 5000 Odense C, Denmark. ${ }^{6}$ Chiropractic Knowledge Hub, University of Southern Denmark, Campusvej 55, 5230 Odense M, Denmark. ${ }^{7}$ Doktor Jensen Akupunkturklinik, Anders Billes Vej 2 B, 7000 Fredericia, Denmark. ${ }^{8}$ Osteopath, Danske Osteopater and Q KLINIK, Finsensvej 42, 2000 Frederiksberg, Denmark. ${ }^{9}$ The Multidisciplinary Pain Center (Section 7612), Rigshospitalet, Blegdamsvej 9, 2100 Copenhagen $\varnothing$, Denmark.
\end{abstract}

The original article can be found online at https://doi.org/10.1186/s10194021-01298-4.

* Correspondence: lotteskytte.kroell@regionh.dk

'Department of Neurology, Danish Headache Centre, Rigshospitalet-Glostrup, University of Copenhagen, Valdemar Hansens Vej 5, 2600 Glostrup, Denmark Full list of author information is available at the end of the article
Published online: 06 October 2021

\section{Reference}

1. Krøll et al (2021) Manual joint mobilisation techniques, supervised physical activity, psychological treatment, acupuncture and patient education for patients with tension-type headache. A systematic review and metaanalysis. J Headache Pain 22:96. https://doi.org/10.1186/s10194-021-01298-4

C C The Author(s). 2021 Open Access This article is licensed under a Creative Commons Attribution 4.0 International License, which permits use, sharing, adaptation, distribution and reproduction in any medium or format, as long as you give appropriate credit to the original author(s) and the source, provide a link to the Creative Commons licence, and indicate if changes were made. The images or other third party material in this article are included in the article's Creative Commons licence, unless indicated otherwise in a credit line to the material. If material is not included in the article's Creative Commons licence and your intended use is not permitted by statutory regulation or exceeds the permitted use, you will need to obtain permission directly from the copyright holder. To view a copy of this licence, visit http://creativecommons.org/licenses/by/4.0/. The Creative Commons Public Domain Dedication waiver (http://creativecommons.org/publicdomain/zero/1.0/) applies to the data made available in this article, unless otherwise stated in a credit line to the data. 